\title{
Cowpox virus infection from pet rat
}

Uwe Wollina', Gesina Hansel', Jacqueline Schönlebe ${ }^{2}$

'Department of Dermatology and Allergology Academic Teaching Hospital Dresden-Friedrichstadt, Dresden, Germany,
${ }^{2}$ Institute of Pathology, "Georg Schmorl", Academic Teaching Hospital Dresden-Friedrichstadt, Dresden, Germany

Corresponding author: Prof. Dr. Uwe Wollina, E-mail: wollina-uw@khdf.de

\begin{abstract}
Cowpox virus belongs to the genera of double-stranded DNA orthopoxviruses. Although it has a low pathogenicity for humans, transmission from infected animals like rodents and cats to humans has been observed. We report on a 19-year-olf female patient who presented with oculo-cutaneous ulcerations and lymphadenopathy, fever and general malaise. Detailed medical history, contact to infected pet rats, histopathology, and course confirmed the diagnosis of human cowpox. Human cowpox is rare but seems to be an emerging disease transmitted in most cases by pets to humans. There is yet no specific treatment available.
\end{abstract}

Key words: Orthopoxvirus; Cowpox; Rodents; Humans; Oculo-cutaneous ulcers; Lymphadenopathy

\section{INTRODUCTION}

Poxviruses are the largest double-stranded DNA viruses which replicate in the cytoplasm of host cells. The human-pathogeneic poxviruses belong to several genera: orthopoxvirus, parapoxvirus, yatapoxvirus, camelpox virus, molluscipoxvirus, etc. [1].

Cowpox virus belongs to genera orthopoxvirus - a heterogeneous group of viruses that infect a broad spectrum of wild rodents and domestic animals, but seem to be restricted to the Old World [2,3].

Human cowpox is a relatively rare zoonotic infection. The largest case review is based on 54 cases investigated from 1969-1993 [4]. Smaller outbreaks have been reported after turn of the century from France and Germany caused by transmission from pets [5-7].

Human cowpox can be acquired by implantation of a virus into injured skin after contact with infected animals, mostly cats or rats. The sero-prevalence among cats has been calculated between $2 \%$ to $4 \%[4,8]$. Small rodents, such as voles and mice, are considered a natural reservoir. No transmission between humans has been reported so far [1-3].
Theincubation period lasts 8-12 days. In immunocompetent humans, cowpox remains a localized skin disease with or without local lymphadenopathy. The lesions start as erythematous macules developing into papules and seropapules, followed by ulcerated plaques with eschar formation. Healing is delayed and often accompanied by scar formation and takes several weeks [4].

More severe courses have been described in patients with atopic dermatitis [9], Darier's disease [10], and systemic corticosteroid therapy [4]. Fatal infections were reported in a patient with atopic dermatitis and allergic bronchial asthma who was receiving systemic steroids at the time of infection [11] and in a 17-year-old boy after kidney transplantation [12]. Most of the reported cases occurred among children and adolescents [4].

Hands and fingers and hands are most commonly affected, followed by face and neck [4]. There are also documented cases of complicated eyelid involvement and bilateral pneumonia from Finland and Germany $[6,13]$.

The diagnosis is problematic because the disease is rare, specific tests are not widely available, therefore clinical assessment is essential. 


\section{CASE REPORT}

A 19-year-old woman presented with painful ulcerated lesions on face, conjunctiva and lower arm. There was a painful lymphadenopathy as well. She had fever and general malaise. Her medical history was unremarkable. She had not medications.

On examination, we observed inflammatory plaques with a central depressed ulceration, minor oozing and raised, sharp borders above the left mandible and on the flexural left lower arm, surrounded by erythema with a maximum diameter of $7 \mathrm{~cm}$. A similar lesion was observed on the conjunctiva of the left lower lid. A single seropapule was noted on the left cheek. Regional lymph nodes on the neck were swollen and painful on pressure (Figs. la - d).

The working diagnosis was oculo-cutaneous tularemia.

Laboratory investigations demonstrated an increased blood sedimentation rate of $30 \mathrm{~mm} / \mathrm{h}$ (normal range $<20)$, C-reactive protein of $82.6 \mathrm{mg} /(<5), 1,334 / \mu \mathrm{l}$ erythrocytes in urine $(<15)$. Serological tests for herpes, tularemia, leptospirosis, and listeriosis were negative. Microbial swabs from the ulcerated lesions remained negative in culture.

A diagnostic skin biopsy was performed from a lesion on the lower arm, formalin-fixed and stained with hematoxylin-eosin, Giemsa stain, periodic acid-Schiff reaction (PAS), and Prussian blue reaction.

Histologic examination demonstrated deep seated hemorrhagic necrosis and necrotic hair follicles. Epidermal acanthosis was noted around the ulcer. Here, ballooning degeneration of keratinocytes and hair follicle epithelium, necrotic keratinocytes and basophilic cytoplasmatic inclusion (Guarnieri) bodies were observed. Within dermis and subcutis, a dense lymphocytic infiltrate with some neutrophilic and esosinophilic granulocytes and individual mast cells was present. Giant cells of Touton- and foreign body-type were occasionally noted (Fig. 2).

Oral antibiosis with sultamicillin $3 \times 1.5 \mathrm{~g} / \mathrm{d}$ and doxycycline 2 x $100 \mathrm{mg} / \mathrm{d}$ initiated under the suspicion of tularemia was ineffective and ulcers enlarged. The lymphadenopathy was persistent (Fig. 1c). The patient developed a maculo-papular exanthema 2 weeks later, that was treated by topical betamethasone ointment and oral levocetericine 2 x $5 \mathrm{mg} / \mathrm{d}$.

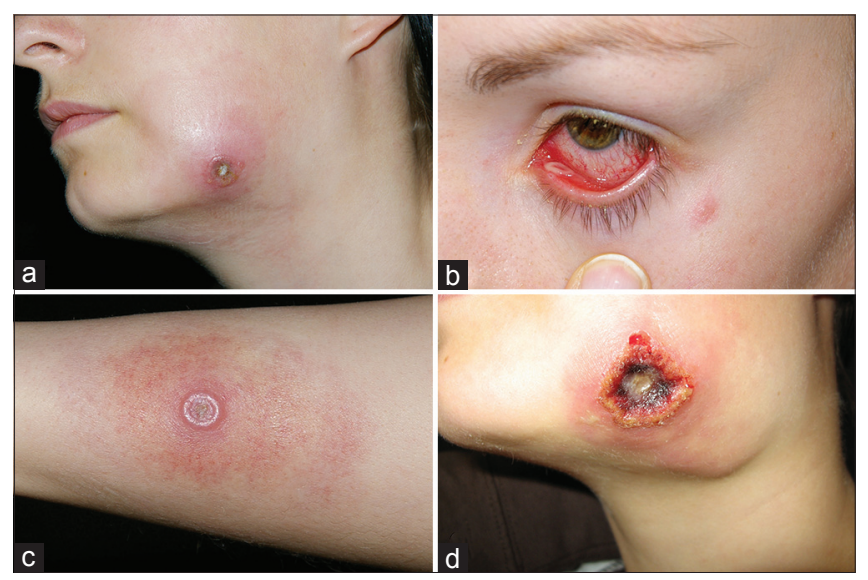

Figure 1: Human cowpox. (a) Facial ulcer with elevated margins. (b) Conjunctival ulcer with blepharitis. (c) Rounded plaque with elevated borders and surrounding erythema on the lower arm. (d) Progressive ulceration 11 days later with lymphadenopathy.

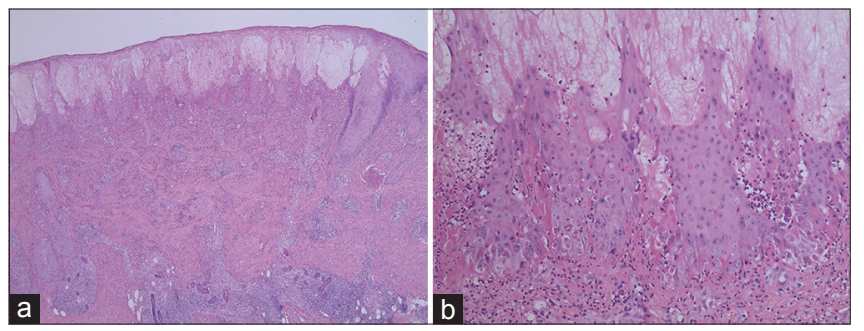

Figure 2: Human cowpox histology (Hematoxylin-eosin). (a) Epidermal acanthosis with ballooning keratinocytes, lympho-monocytic dermal infiltrate $(x 2)$. (b) Detail showing ballooning degeneration of keratinocytes, necrotic keratinocytes and basophilic cytoplasmatic inclusions. In the upper dermis, there is an inflammatory infiltrate with some intermingled giant cells.

After repeated questioning, it became clear that she had 3 pet rats at home suspicious of mite infestation, one of them died. She remembered rat bites in her fingers.

The rat was later presented to veterinary medicine where foot pad lesions were noted comparable with cowpox infection. It became clear that the mite infestation was a misdiagnosis.

The diagnosis of a human cowpox virus infection transmitted by a pet rat was confirmed.

The patient was treated by good ulcer care for open wounds. The lesions eventually healed by scarring after eight weeks. There was no relapse during follow-up of 8 years.

\section{DISCUSSION}

Tularemia was the first suspicion in our young patient with oculo-cutaneous lesions combined with lymphadenopathy. Tularemia is caused by gram-negative 
coccobacillus Francisella tularensis and re-emerged in Germany in 2004. F. tularensis had been identified in yellow-necked field mice (2.9\%), bank voles (4.5\%), common voles $(8.0 \%)$, field voles $(10.0 \%)$, and water voles $(15.0 \%)$ [14]. The clinical presentation is highly variable. The diagnosis was excluded later based on exposure to pet cowpox infected rats, histopathology, and clinical course.

Cowpox virus has relatively low pathogenicity for humans but has a wide range of sensitive animal hosts. Human cowpox is a rare sporadic disease, which develops when the virus is transmitted from an infected animal to humans. This disease is mainly recorded in Europe [1].

Pet dog and cat populations have substantially increased in the developed world and it is estimated that dogs and cats are present in more than $50 \%$ of households in the USA and Europe [15]. In a study on feline cowpox infection, a remarkable genetic heterogeneity of genetic virus variants was reported that translates also into variable virulence [16].

Pet rats have become popular domestic animals. Their claws may produce scratches and punctures, unnoticed by the owner and thereby inoculate the cowpox virus. Infected rats like cats most frequently develop ulcers on the legs, toes, footpads, faces, and ears $[7,17]$. In the present case, several finger bites by pet rats were remembered by the patient.

There have been several reports on outbreaks of cowpox virus infections in humans transmitted from pet rats in Germany and France. There is a report about 4 patients with cowpox infections form pet rats in 2008 and 2009 from France. Affection of skin, eyes and mucous membranes with coughing, lymphadenopathy, fever and general malaise were observed [5]. In 2008, in the region of Krefeld, Germany, six patients were affected with one case of severe eye involvement and another case with pulmonary infections [6]. In 2009, an outbreak of ulcero-cutaneous cowpox was reported in greater Munich area, Germany, with five affected patients who had bought rats form the same litter [18]. In 2011, eight patients were affected in Munich, Germany [7]. Most patients developed seropapules, some ulcerated plaques with or without lymphadenopathy. In the same year four cases have been reported from France with ulcero-cutaneous lesions [19].

Neurogenic inflammation is a possible symptom of persistent cowpox infection [20]. Severe ear chondritis developed from cowpox transmitted from a pet rat [21]. Generalized cowpox infection has been described in HIV-positive patients [22].

The differential diagnosis comprises a broad range of infectious diseases: bacterial (atypical mycobacteriosis, cat scratch disease, ecthyma, pyodermia, ulcerocutaneous tularemia, cutaneous anthrax, rickettsial infections, actinomycosis, syphilis maligna), fungal (sporotrichiosis, blastomycosis), viral (smallpox, monkeypox, herpes simplex, varicella zoster infections, milker's nodules, orf). An initial skin lesion can resemble drug eruption, insect bite or pyoderma gangrenosum. For biosafety reasons, a prompt diagnosis is essential in multifocal cases resembling smallpox [4].

Laboratory methods to detect cowpox virus include electron microscopy tungstic acid-stained native material, real-time polymerase chain reaction (PCR) and semi-nested PCR. Serological tests are indirect methods. For interpretation, vaccination against smallpox with vaccinia virus must be considered [23-25].

The treatment of the mostly self-limiting illness is symptomatic by wound care. Surgical interventions may prolong the healing process. Antibiotic treatment is required only in patients with a bacterial superinfection [6].

Steroids are contraindicated and may exacerbate the disease. The use of antiviral treatment with cidofovir or anti-vaccinial-hyperimmunoglobulin is discussed controversial. These options should be reserved for very severe disease courses and personal at high risk of infection. The use of antiviral drugs in human cowpox is off-label $[26,27]$.

\section{Key messages}

- Cowpox is an orthopoxvirus disease of emerging importance.

- Small rodents are the natural reservoir of cowpox virus.

- Pets like cats and rats are major transmitters of cowpox from animal to humans.

- In most cases the disease is self-limited but fatal cases have been observed in immunosuppressed patients.

\section{Consent}

The examination of the patient was conducted according to the Declaration of Helsinki principles. 


\section{REFERENCES}

1. Shchelkunov SN. An increasing danger of zoonotic orthopoxvirus infections. PLoS Pathog. 2013;9:e1003756.

2. Chantrey J, Meyer H, Baxby D, Begon M, Bown KJ, Hazel SM, et al. Cowpox: reservoir hosts and geographic range. Epidemiol Infect. 1999;122:455-60.

3. Hoffmann D, Franke A, Jenckel M, Tamošiūnaite A, Schluckebier J, Granzow H, et al. Out of the reservoir: phenotypic and genotypic characterization of a novel cowpox virus isolated from a common vole. J Virol. 2015;89:10959-69.

4. Baxby D, Bennett M, Getty B. Human cowpox 1969-93: a review based on 54 cases. Br J Dermatol. 1994;131:598-607.

5. Ninove L, Domart Y, Vervel C, Voinot C, Salez N, Raoult D, et al. Cowpox virus transmission from pet rats to humans, France. Emerg Infect Dis. 2009;15:781-4.

6. Becker C, Kurth A, Hessler F, Kramp H, Gokel M, Hoffmann R, et al. Cowpox virus infection in pet rat owners: not always immediately recognized. Dtsch Arztebl Int. 2009;106:329-34.

7. Vogel S, Sárdy M, Glos K, Korting HC, Ruzicka T, Wollenberg A. The Munich outbreak of cutaneous cowpox infection: transmission by infected pet rats. Acta Derm Venereol. 2012;92:126-31.

8. Nowotny N. Serologic studies of domestic cats for potential human pathogenic virus infections from wild rodents. Zentralbl Hyg Umweltmed. 1996;198:452-61.

9. Pelkonen PM, Tarvainen K, Hynninen A, Kallio ERK, Henttonen $\mathrm{H}$, Palva A, et al. Cowpox with severe generalized eruption, Finland. Emerg Infect Dis. 2003;9:1458-61.

10. Haase O, Moser A, Rose C, Kurth A, Zillikens D, Schmidt E. Generalized cowpox infection in a patient with Darier disease. $\mathrm{Br}$ J Dermatol. 2011;164:1116-8.

11. Czerny CP, Eis-Hübinger AM, Mayr A, Schneweis KE, Pfeiff B. Animal poxviruses transmitted from cat to man: current event with lethal end. Zentralbl Veterinarmed B. 1991;38:421-31.

12. Gazzani P, Gach JE, Colmenero I, Martin J, Morton H, Brown K, et al. Fatal disseminated cowpox virus infection in an adolescent renal transplant recipient. Pediatr Nephrol. 2017;32:533-6.

13. Kinnunen PM, Holopainen JM, Hemmilä $H$, Piiparinen $H$, Sironen T, Kivelä T, et al. Severe ocular cowpox in a human, Finland. Emerg Infect Dis. 2015;21:2261-3.

14. Kaysser P, Seibold E, Mätz-Rensing K, Pfeffer M, Essbauer S, Splettstoesser WD. Re-emergence of tularemia in Germany: Presence of Francisella tularensis in different rodent species in endemic areas. BMC Infect Dis. 2008;8:157.

15. Chomel BB. Emerging and re-emerging zoonoses of dogs and cats. Animals (Basel). 2014;4:434-45.

16. Kaysser P, von Bomhard W, Dobrzykowski L, Meyer H. Genetic diversity of feline cowpox virus, Germany 2000-2008. Vet Microbiol. 2010;141:282-8.

17. Kuczka A, Nitsche A, Höveler R, Becker C, Kurth A. Seltene Zoonose vermehrt in Deutschland nachgewiesen. Ein Bericht über durch Heimtierratten auf Menschen übertragene Kuhpockeninfektion. Dtsch Tierärztebl. 2009;5:316-9.

18. Campe H, Zimmermann P, Glos K, Bayer M, Bergemann H, Dreweck $C$, et al. Cowpox virus transmission from pet rats to humans, Germany. Emerg Infect Dis. 2009;15:777-80.

19. Ducournau C, Ferrier-Rembert A, Ferraris O, Joffre A, Favier AL, Flusin $\mathrm{O}$, et al. Concomitant human infections with 2 cowpox virus strains in related cases, France, 2011. Emerg Infect Dis. 2013;19:1996-9.

20. Hobi S, Mueller RS, Hill M, Nitsche A, Löscher T, Guggemos W, et al. Neurogenic inflammation and colliquative lymphadenitis with persistent orthopox virus DNA detection in a human case of cowpox virus infection transmitted by a domestic cat. Br J Dermatol. 2015;173:535-9.

21. Elsendoorn A, Agius G, Le Moal G, Aajaji F, Favier AL, Wierzbicka-Hainault E, et al. Severe ear chondritis due to cowpox virus transmitted by a pet rat. J Infect. 2011;63:391-3.

22. Fassbender P, Zange S, Ibrahim S, Zoeller G, Herbstreit F, Meyer H. Generalized cowpox virus infection in a patient with HIV, Germany, 2012. Emerg Infect Dis. 2016;22:553-5.

23. Kurth A, Nitsche A. Detection of human-pathogenic poxviruses. Methods Mol Biol. 2011;665:257-78.

24. Maksyutov RA, Gavrilova EV, Meyer H, Shchelkunov SN. Real-time PCR assay for specific detection of cowpox virus. J Virol Methods. 2015;211:8-11.

25. Abrahão JS, Drumond BP, Trindade Gde S, da Silva-Fernandes AT, Ferreira JM, Alves PA, et al. Rapid detection of orthopoxvirus by semi-nested PCR directly from clinical specimens: a useful alternative for routine laboratories. J Med Virol. 2010;82:692-9.

26. Hostetler KY. Synthesis and early development of hexadecylopropylcidofovir: an oral antipoxvirus nucleoside phosphonate. Viruses 2010;2:2213-25.

27. Petersen BW, Harms TJ, Reynolds MG, Harrison LH. Use of vaccinia virus smallpox vaccine in laboratory and health care personnel at risk for occupational exposure to orthopoxviruses - recommendations of the Advisory Committee on Immunization Practices (ACIP), 2015. MMWR Morb Mortal Wkly Rep. 2016;65:257-62.

Copyright by Uwe Wollina, et al. This is an open-access article distributed under the terms of the Creative Commons Attribution License, which permits unrestricted use, distribution, and reproduction in any medium, provided the original author and source are credited.

Source of Support: Nil, Conflict of Interest: None declared. 